\title{
Korai petefészek-kimerüléssel összefüggő tünetek bio-pszicho-szociális szemléletü kezelése
}

\author{
Szigeti F. Judit dr. ${ }^{1}$ - Ács Nándor dr. ${ }^{2}$ \\ Semmelweis Egyetem, Általános Orvostudományi Kar, ${ }^{1}$ Klinikai Pszichológia Tanszék, \\ ${ }^{2}$ II. Szülészeti és Nőgyógyászati Klinika, Budapest
}

\begin{abstract}
Az egészségügyi tevékenységek minimumfeltételei megszabják, hogy egyes szomatikus osztályokon dolgozzon pszichológus. Az orvosi gyakorlatban mindeközben még nem mondható általánosnak az az attitûd, amely a pszichés tényezőknek a betegségek alakulásában játszott potenciális szerepét is figyelembe veszi. A modern pszichoszomatikus gyógyító szemlélet egyszerre veszi számításba a biológiai, pszichológiai és társas faktorokat, amelyek hajlamosítanak egy betegségre vagy kiváltják és fenntartják azt. Az alábbi esettanulmány egy olyan 35 éves nő kezeléstörténete, akinek tünetei egyszerre bizonyultak a korai petefészek-kimerülés és a szorongás jeleinek, és kölcsönösen hatottak egymásra. Az esetvezetés során a beavatkozások is két síkon: testre ható (hormonterápia, Jacobson-féle progresszív relaxáció) és pszichés eszközökkel történtek (kognitív viselkedésterápiás intervenciók). Az eset jól példázza, hogy orvos és pszichológus együttmúködése miként szolgálhatja a páciens érdekeit.
\end{abstract}

Orv Hetil. 2017; 158(36): 1432-1435.

Kulcsszavak: hőhullám, alvászavar, szorongás, bio-pszicho-szociális szemlélet, kognitív viselkedésterápia

\section{Biopsychosocially informed therapy of symptoms related to premature ovarian failure}

The basic legal conditions for pursuing medical activities in Hungary require that psychologists be employed at certain somatic departments. In the Hungarian medical practice, however, attitudes recognizing the potential role of psychological factors in the course of diseases are not widely present. The modern psychosomatic approach to healing includes biological, psychological and social factors that may predispose one to, precipitate or perpetuate a medical condition. This case study of a 35-year-old woman reports on a therapy in which the symptoms were indicative of both premature ovarian failure and anxiety, influencing each other in a bidirectional way. Therapy also included interventions on physical (hormonal therapy, Jacobson's progressive relaxation technique) and psychological levels (cognitive behavioral interventions). This case management is an example for how physician-psychologist collaboration serves the best interests of patients.

Kulcsszavak: hot flashes, sleep disorder, anxiety, biopsychosocial approach, cognitive behavioral therapy

Szigeti FJ, Ács N. [Biopsychosocially informed therapy of symptoms related to premature ovarian failure]. Orv Hetil. $2017 ; 158(36)$ : 1432-1435.

(Beérkezett: 2017. június 28.; elfogadva: 2017. július 20.)

\section{Rövidítések}

$\mathrm{AMH}=$ anti-Müller-hormon; BAI = (Beck Anxiety Inventory $)$ Beck-féle Szorongás Leltár; BDI $=($ Beck Depression Inventory) Beck-féle Depresszió Kérdőív; CBT = (cognitive behavioral therapy) kognitív viselkedésterápia; $\mathrm{FNE}=$ (Fear of Negative Evaluation Scale) Megmérettetés Kérdőív; FSH = folliculussti- muláló hormon; IVF = (in vitro fertilization $)$ in vitro fertilizáció; POI = (premature ovarian insufficiency) korai petefészekelégtelenség; $\mathrm{POF}=$ (premature ovarian failure) korai petefészek-kimerülés; RSES = (Rosenberg Self-Esteem Scale $)$ Rosenberg-féle Önértékelés Kérdőív 
A test és lélek egységét szem előtt tartó gyógyítás ma különféle formákban és minőségben nyilvánul meg, az ezotériától az alternatív orvosláson keresztül a bio-pszicho-szociális szemléletű terápiákig. A betegségek modern pszichoszomatikus megközelítései, köztük a reproduktív egészségpszichológia, nem feltételez direkt oksági viszonyt lelki és testi jelenségek között, hanem egyszerre veszi számításba a biológiai, pszichológiai és társas faktorok egymásra hatását $[1,2]$. Jelen esettanulmány egy olyan korai petefészek-kimerülésben (POF) szenvedő beteget mutat be, akinek gyógyulási esélyeit jelentősen növelte a szomatikus orvoslás és a pszichoterápia együttes érvényesülése.

A korai petefészek-kimerülés a primordialis folliculusok idő előtti megfogyatkozását jelenti: az eredendően is csökkent mennyiségű tüszők ilyen esetekben már a 40 . életév előtt „elfogynak” [3]. A megbetegedés prevalenciája a 40 évesnél fiatalabb nők körében 1\% [4]. Etiológiája csak az esetek 10\%-ában határozható meg pontosan (autoimmun, kromoszóma- vagy egyéb ritka rendellenességek, onkológiai betegségek radio-, illetve kemoterápiája), a kórállapotok túlnyomó többsége idiopathiás [5]. A POF legjellemzőbb tünete az oligo-, illetve amenorrhoea, valamint a klimaktériumra egyébként is jellemző hőhullámok, éjszakai izzadás, alvászavar és palpitatio [6].

A petefészek-elégtelenség legnyilvánvalóbb következménye az infertilitás: a POF-ben szenvedő nők mindöszsze 5-10\%-ánál van intermittens ovariumfunkció folytán esély a spontán teherbe esésre [4]. A sterilitáson a petesejt- vagy preembrió-adományozással kiegészített in vitro fertilizáció segíthet $[7,8]$. A POF hosszabb távú egészségügyi következményei közt a szexuális diszfunkciók (hüvelyszárazság, dyspareunia), a cardiovascularis megbetegedések, a dementia és az osteoporosis megnövekedett kockázata említendő [9].

Mint a menopausa általában, a POF is kedvezőtlen hatással van az érintettek pszichés jóllétére és életminőségére. Korai petefészek-elégtelenséggel diagnosztizált nők körében a normatív adatoknál magasabb a depreszszió- és észlelt stressz-szint, valamint alacsonyabb az önértékelés és az élettel való elégedettség [10]. Az orvosi kezelés mellett zajló pszichoterápia, elsősorban a kognitív viselkedésterápia nemcsak a vazomotoros tünetek előfordulását, hanem azok szubjektív terhét is csökkentheti és az életminőséget is javíthatja [11].

\section{Anamnézis}

POF-ben szenvedő 35 éves betegünk szomatikus anamnéziséből kiemelendő a korai menarche, menorrhagia, ovarialis cysták, migrénes fejfájás. Huszonöt éves kora óta rendszeresen tapasztal melegségérzettel, heves szívdobogással és izzadással járó kellemetlen közérzetet, amit eleinte rohamos súlygyarapodás kísért. Ciklusának beállítása fogamzásgátló alkalmazásával történt. Ezt 28 éves korában gyermekvállalási szándékból elhagyta, amit azonban amenorrhoea követett, ezért hormonszubsztitúcióra került sor. Későbbi vizsgálatakor a ciklus eleji emelkedett basalis FSH-szint (>30 U/L) és a hypoestrogenismus csökkent petefészek-rezervkapacitást jelzett, amit az anti-Müller-hormon- $(\mathrm{AMH}<0,21 \mathrm{ng} / \mathrm{ml})$ vizsgálat is igazolt. Inzulinrezisztenciájának gyógyszeres kezelése jelentős súlycsökkenéshez vezetett, de teherbe esés nem következett be. Az asszisztált reprodukciós célú ovarialis stimuláció nem eredményezett megfelelő tüszőérést. A hőhullámok nem enyhültek, ezért hormonterápiát kezdtünk (tibolon, 2,5 mg/nap), néhány hónappal később azonban észleltük, hogy a gyógyszeres kezelés önmagában nem elegendő a panaszok csökkenéséhez, ezért a kezelést pszichológiai ellátással egészítettük ki.

Pszichológiai anamnéziséből említést érdemel az iskolai szerepléstől való extrém szorongás, valamint a megszégyenülés a másodlagos nemi jegyek korai megjelenése és a medikusok körében zajló sorozatos gyermek-nőgyógyászati vizsgálatok miatt. Közlekedéskor a szemkontaktust és az egyedüllétet 25 éves kora óta kerülte. Jelentkezéskor ingerlékenynek érezte magát, koncentrációs nehézségekkel küzdött. Énképe negatív volt, „selejtnek, genetikai hulladéknak" érezte magát.

Betegünk már a diagnosztikai folyamat során is a szomatikus és a pszichés tünetek együttes figyelembevételét igényelte. A beteg vazomotoros szimptómáit a korai menopausa indokolhatja [6]. Az ingerlékenység és a koncentrációs nehézségek a kialvatlansággal és az ovarialis hormonfluktuációval is kapcsolatban állhatnak [12]. A mások figyelmének való kitettség félelme és az elkerülő magatartás viszont nem a szomatikus állapot tünetei: ezeket legjobban a szociális fóbia diagnózis magyarázza.

\section{Kezelés}

A húszalkalmas pszichoterápia első fázisában az alvásdeficit csökkentését céloztuk meg. Az alvászavar kezelésében az insomnia kognitív terápiájának néhány elemét: alváshigiénés és életmód-tanácsadást, optimális alvási viselkedés és környezet kialakítását, hyperarousal csökkentését alkalmaztuk [13], aminek hatására a probléma lényegesen oldódott.

A terápia további részében a társas helyzetektől való szorongás és a hőhullámok terhének enyhítése volt a cél, ezért a szociális fóbia [14] és a változókori tünetek [15] kognitív terápiájának elemeit kombináltuk. Stresszkezelés céljából a Jacobson-féle progresszív relaxációt és légzéskontrollt alkalmaztuk. A beteg megfigyelte, hogy ha a hőhullám első pillanataiban izomszorítást alkalmaz, akkor kevésbé önti el a forróság. Megtanult a hőhullámainak nem túl nagy jelentőséget tulajdonítani, és elfogadni, hogy azok jönnek és elmúlnak. A hőhullámnapló megerősítette, hogy azok főként szorongással járó társas helyzetekben jelentkeznek, kellemetlen érzéseket okozó gondolatokkal összefüggésben. Korrigáltuk a beteg gondolati torzításait, például potenciális alternatív magyarázatokat találtunk az emelkedett hőérzetre (magas külső 
hőmérséklet, mozgás, alkoholfogyasztás). Ennek köszönhetően a vazomotoros tünetek mind számban, mind intenzitásban csökkentek. Mindez a farmakoterápiát nem befolyásolta: osteoporosis megelőzése céljából a páciens a gyógyszert ugyanolyan adagolásban szedte tovább.

Ahhoz, hogy a beteg önmagával kapcsolatos „Selejt vagyok!” meggyőződését módosíthassuk, szükséges volt, hogy a különböző embertípusokat, köztük saját magát is elhelyezze egy „értékességi viszonyító skálán”, így önértékelése differenciáltabbá és reálisabbá vált. Termékenységi nehezítettségével kapcsolatos szemlélete szintén megváltozott: míg ez korábban csak növelte általános alkalmatlanságérzetét, most fokozatosan belátta, hogy bár nagyon szeretne gyermeket, emberi értékei nem ettől függnek.

A terápia utolsó szakaszában a páciens tünetfenntartó viselkedésén igyekeztünk változtatni. A beteg listát készített a számára szorongást okozó tevékenységekről, és nehézségi fokuk alapján sorrendbe helyezte, majd figyelmi fókuszát önmagáról a környezetre irányítva sorra végrehajtotta őket, ezzel megtapasztalva, hogy előrevetített félelmei nem válnak valóra. A szorongásvezérelt magatartást a mindennapjai során is természetesebb viselkedésformákra cserélte. Életvezetésében egyre nagyobb önállóságot vállalt, konfliktuskezelése javult. A terápia elején és végén alkalmazott pszichodiagnosztikai mérőeszközök pozitív változást jeleztek: a páciens szorongása közepesról alacsony szintre (BAI: 30-ról 14 pontra), depressziószintje középsúlyosról az enyhe szint alsó határára (BDI: 24-ről 10 pontra), a társas helyzetektől való félelme nagyfokúról kismértéküre csökkent (FNE: 23ról 13 pontra), önértékelése pedig alacsonyról átlagosra (RSES: 5-ról 16 pontra) emelkedett.

A terápia végén a páciens és férje ismét jelentkezett egy reprodukciós problémákat kezelő klinikán. A pszichoterápia lezárása után másfél évvel a páciens oocytadonáció alkalmazása révén egészséges kislányt szült.

\section{Megbeszélés}

Terápiánk sikerét leginkább az segítette elő, hogy a menopausalis hőhullámok és a szorongásos reakciók testi tünetei között felfigyeltünk a lehetséges átfedésekre [16]. Míg a hőhullámok a szexuálszteroid-szintek ingadozásával esnek egybe, addig - ha egy személy zavarba jön - adrenalinfelszabadulás következik be [11]. Közös azonban ezek hatása: az elpirulás, az arc perifériás ereinek kitágulása, ami a szociális szorongás gyakori tünete. Egy tanulmány „elhanyagolt szorongásos zavarként” említi a szociális fóbiát, és felhívja a figyelmet arra, hogy a nőgyógyászati diagnózist követő pszichés problémával kezelt betegek esetén is érdemes ellenőrizni, nincs-e a háttérben kezeletlen szociális szorongás [17].

Ugyancsak fontos volt páciensünk alvásproblémájának rendezése, hiszen a rosszabbul alvó változókorú nők éb- redés után hajlamosak túlbecsülni éjszakai hőhullámaik számát [18]. Hasonló jelentőséggel bírt a stresszkezelés, hiszen a szorongó változókorúak gyakrabban észlelik a tüneteket [19], mint a nem szorongók. További meggondolás tárgyát képezte betegünk szomatizációs hajlama, ugyanis azok a nók, akiket a testi tünetek fokozott monitorozása, a szomatizáló tünetpercepció és attribúciós stílus jellemez, különösen érzékenyek a változókori testi panaszokra [20].

Páciensünk állapotjavulását a menopausa-tünetek és a szociális szorongás komplex kezelésével értük el. A szociális fóbia kognitív modellje szerint a társas szorongók saját megnyilvánulásaikat élénken figyelik, és magukat másoknál butábbnak, unalmasabbnak vagy legalábbis tőlük eltérőnek érzik. Megszégyenülés ellen óvintézkedéseket tesznek, így viszont esélyük sincs megtapasztalni, hogy a rettegett katasztrófák nem feltétlenül következnek be [21]. Az alkalmazott gyakorlatok ezek semlegesítését célozták meg. A változókori tünetek kognitív modellje szerint a klimaktérium negatív értékelése, a panaszok kontrollálhatatlanságának érzete növeli a tünetek okozta distresszt [22]. Ezt a folyamatot páciensünk esetében sikerült megfordítani.

Bár a korai petefészek-elégtelenség (POI) kezelésének nemzetközi irányelveit csak 2015-ben dolgozták ki, a jelenleg forgalomban lévő ajánlások a pszichológiai intervenciók és életmód-tanácsadás elérhetővé tételét javasolják, mind a POI [9], mind pedig általában a menopausa [23] ellátásában. A protokollok a fenti kórképekben nőgyógyászati kezelés mellett - szorongás esetén elsőként pszichoterápiát (CBT), hangulatjavításra hormonpótló és pszichoterápia együttes alkalmazását javasolják; antidepresszánsokat (szelektív szerotonin- és noradrenalinvisszavétel-gátlókat) csak nagy körültekintéssel, indokolt esetben ajánlanak.

Összességében megfontolandó a biológiai terápia kibővítése pszichológiai beavatkozással olyan esetekben, amikor egy betegség lefolyása atipikus, szomatikus okokkal nehezen magyarázható tünetek vannak jelen, vagy a páciens anamnézise, beszámolója pszichés faktorok meglétére enged következtetni.

\section{Következtetés}

Esetünk példázza, hogy az organikus versus pszichogén kérdésfeltevést legjobban nem vagy-vagy, hanem is-is alapon, cirkuláris szemléletben érdemes megközelíteni. A nőgyógyász részéról megvalósult az az érzelmi ráhangolódás, amely során a szomatikus betegségtudat pszichoszomatikus formában is megjelenhet [24]. A pszichológus sem tévesztette szem elől a testi folyamatokat, nem igyekezett minden tünetnek lelki okot tulajdonítani. Összességében a multidiszciplináris megközelítés betegünk javára vált. 
Anyagi támogatás: A közlemény megírása anyagi támogatásban nem részesült.

Szerzői munkamegosztás: Sz. F. J.: Témafelvetés, irodalomkutatás, a kézirat megszövegezése. Á. N.: A kézirat nőgyógyászati kiegészítése és értékelése. A cikk végleges változatát mindkét szerző elolvasta és jóváhagyta.

Érdekeltségek: A szerző́knek nincsenek érdekeltségeik.

\section{Köszönetnyilvánítás}

Köszönjük Kiss Zsófia és Szita Bernadett klinikai szakpszichológusok észrevételeit, és betegünk hozzájárulását a közléshez.

\section{Irodalom}

[1] Lal M. Psychosomatic approaches to obstetrics, gynaecology and andrology - a review. J Obstet Gynaecol. 2009; 29: 1-12.

[2] Pápay N, Rigó A. Introduction. In: Pápay N, Rigó A. (eds.) Reproductive health psychology. [Bevezető. In: Pápay N, Rigó A. (szerk.) Reproduktív egészségpszichológia.] ELTE Eötvös Kiadó, Budapest, 2015; pp. 7-9. [Hungarian]

[3] Papp Z. (ed.) Handbook of obstetrics and gynaecology. Second multimedia edition. Fourth edition. [A szülészet-nőgyógyászat tankönyve. Második multimédia kiadás. Negyedik kiadás.] Semmelweis Kiadó, Budapest, 2009. [Hungarian]

[4] Goswami D, Conway GS. Premature ovarian failure. Hum Re prod Update 2005; 11 : 391-410.

[5] Arora P, Polson DW. Diagnosis and management of premature ovarian failure. Obstetrician \& Gynaecologist 2011; 13: 67-72.

[6] Beck-Peccoz P, Persani L. Premature ovarian failure. Orphanet J Rare Dis. 2006; 1: 9

[7] De Vos M, Devroey P, Fauser BC. Primary ovarian insufficiency. Lancet 2010; 376: 911-921.

[8] Urbancsek J, Bárándi Zs, Sztanyik L. Fertilization outside the body. In: Urbancsek J, Papp Z. (eds.) Gynaecological endocrinology. [Szervezeten kívüli megtermékenyítés. In: Urbancsek J, Papp Z. (szerk.) Nőgyógyászati endokrinológia.] Springer Hungarica Kiadó, Budapest, 1997; pp. 287-380. [Hungarian]

[9] European Society for Human Reproduction and Embryology (ESHRE) Guideline Group on POI, Webber L, Davies M, Anderson R, et al. Management of women with premature ovarian insufficiency. Hum Reprod. 2016; 31: 926-937.

[10] Liao KL, Wood N, Conway GS. Premature menopause and psychological well-being. J Psychosom Obstet Gynaecol. 2000; 21 : 167-174

[11] Mann E, Smith M, Hellier J, et al. A randomised controlled trial of a cognitive behavioural intervention for women who have menopausal symptoms following breast cancer treatment (MENOS 1): Trial protocol. BMC Cancer 2011; 11: 44

[12] Gordon JL, Girdler SS, Meltzer-Brody SE, et al. Ovarian hormone fluctuation, neurosteroids and HPA axis dysregulation in perimenopausal depression: A novel heuristic model. Am J Psychiatry $2015 ; 172$ : 227-236.
[13] Purebl Gy. The power of mind over body. Cognitive therapy for insomnia. In: Perczel Forintos D. (ed.) New developments in cognitive therapy. [A gondolat hatalma a test felett. Az inszomnia kognitív terápiája. In: Perczel Forintos D. (szerk.) A kognitív terápia fejlődése.] Akadémiai Kiadó, Budapest, 2011; pp. 93108. [Hungarian]

[14] Perczel Forintos D. Cognitive behavioral therapy for social phobia. In: Perczel Forintos D, Mórotz K. (eds.) Cognitive behavioral therapy. [A szociális fóbia kognitív viselkedésterápiája. In: Perczel Forintos D, Mórotz K. (szerk.) Kognitív viselkedésterápia.] Medicina Könyvkiadó, Budapest, 2005; pp. 337-367. [Hungarian]

[15] Hunter MS, Coventry S, Hamed H, et al. Evaluation of a group cognitive behavioural intervention for women suffering from menopausal symptoms following breast cancer treatment. Psychooncology 2009; 18: 560-563.

[16] Hanisch L, Hantsoo L, Freeman EW, et al. Hot flashes and panic attacks: a comparison of symptomatology, neurobiology, treatment and a role for cognition. Psychol Bull. 2008; 134: 247269.

[17] Akechi T, Okuyama T, Sagawa R, et al. Social anxiety disorder as a hidden psychiatric comorbidity among cancer patients. Palliat Support Care 2011; 9: 103-105.

[18] Fu P, Matthews KA, Thurston RC. How well do different measurement modalities estimate the number of vasomotor symptoms? Findings from the Study of Women's Health Across the Nation FLASHES Study. Menopause 2014; 21: 124-130.

[19] Freeman EW, Sammel MD, Lin H, et al. The role of anxiety and hormonal changes in menopauzal hot flashes. Menopause 2005; 12: $258-266$

[20] Szita B. Biological and psychosocial features of menopause. In: Pápay N, Rigó A. (eds.) Reproductive health psychology. [A menopauza biológiai és pszichoszociális jellemzői. In: Pápay N, Rigó A. (szerk.) Reproduktív egészségpszichológia.] ELTE Eötvös Kiadó, Budapest, 2015; pp. 133-157. [Hungarian]

[21] Clark DM, Wells A. A cognitive model of social phobia. In: Heimberg R, Liebowitz M, Hope DA, et al. (eds.) Social phobia: diagnosis, assessment and treatment. Guilford Press, New York, 1995; pp. 69-93.

[22] Hunter MS, Mann E. A cognitive model of menopausal hot flushes and night sweats. J Psychosom Res. 2010; 69: 491-501.

[23] National Institute for Health and Care Excellence. Menopause: diagnosis and management. NICE guideline [NG23]. Published date: November 2015. Available from: https://www.nice.org. uk/guidance/ng23 [accessed: June 26, 2017].

[24] Szakács K. Psychotherapy. In: C Molnár E, Füredi J, Papp Z. (eds.) Obstetric and gynaecological psychology and psychiatry. [Pszichoterápia. In: C. Molnár E, Füredi J, Papp Z. (szerk.) Szülészet-nőgyógyászati pszichológia és pszichiátria.] Medicina Könyvkiadó, Budapest, 2006; pp. 361-372. [Hungarian]

(Szigeti F. Judit dr., Budapest, Tömő u. 25-29. III. e., 1083 e-mail: szigetifjudit@gmail.com) 